\title{
Capillary water absorption in mixtures of cohesive soils stabilized with cement and hydrophobic agent
}

\author{
Szymon Węgliński \\ Faculty of Civil and Transport Engineering; Institute of Civil Engineering; \\ Poznań University of Technology; 5 Piotrowo St., 60-965 Poznań, Poland; \\ szymon.weglinski@put.poznan.pl iD 0000-0002-0830-8152
}

\begin{abstract}
The paper presents the results of research on capillary water absorption of mixtures from cohesive soils - loamy sand and sandy loam - stabilized with cement and the addition of a hydrophobizing agent. The research showed that the appropriate addition of diamidoamine lactate allows to limit the penetration of water inside the stabilized samples, which increases their frost resistance. The mixtures with the additive showed lower capillary water absorption compared to the mixtures stabilized with cement only, especially in the first few hours after soaking with water.
\end{abstract}

Keywords: stabilization of cohesive soils; a hydrophobizing agent; diamidoamine lactate; frost resistance, capillary absorption

\section{Introduction}

Due to the problem of weak ground that appears in large numbers in road construction, special attention should be paid to its proper preparation. There are many ways to strengthen the ground (including soil replacement or indirect foundation), which, despite their high efficiency in improving mechanical parameters, generate significant costs. The author believes that in the implementation of construction works, local raw materials and waste materials should be used in the first place. In road construction, such a material, due to low strength parameters (e.g. angles of internal friction or compressibility modules), as well as susceptibility to increased plasticity under the influence of water and volume changes resulting from frost damage, are cohesive soils, which cannot be present in the roadbed.

When water changes from liquid to solid (ice), it increases in volume by approx. $9 \%$. The increase in volume, when water freezes, is not the main cause of blows - it is the formation of ice lenses in the ground. The lenses grow as a result of rising water from damp places or from aquiferous soil (capillary rise phenomenon). The situation occurs when the soil contains a large amount of clay particles and a dusty fraction [1]. 
A commonly used solution for soil improvement is soil stabilization with hydraulic binders. The most effective method is to stabilize non-cohesive soils with cement. Due to the need to reduce costs during the implementation of investments, it seems beneficial to improve local land, even potentially considered useless.

In the case of cohesive soils, where drainage of water into the depth - due to fine graining and low permeability - is impossible, increasing ice crystals cause uplift of the soil layer. The height of the debris depends on the amount of ice that forms in the ground. The amount of ice depends on the initial soil moisture content, frost exposure time, temperature gradient, grain size, water permeability, thermal conductivity and chemical composition [1], [2]. It is, therefore, important to limit the possibility of water absorption from the surroundings into the cohesive soil layers.

Summarizing the analysis of the literature on the stabilization of cohesive soils [3] - [6], it should be stated that the addition of only cement to the soil as the sole hydraulic binder does not guarantee the compressive strength required by the standard [7]. Moreover, only in a few cases the expected level of frost resistance of the layers was achieved. For binders other than cement, the obtained results are generally worse. The maximum, standard amount of the additive (not more than 10\% [7]) does not allow obtaining repeatable results confirming the required compressive strength and frost resistance of the stabilized layer.

Hydrophobizing additives can be used to limit water penetration inside cement-stabilized layers. The researchers started to look for some alternative and high performance materials that are industrially manufactured like crystallising materials, moisture blockers, cementitious coatings and silicate materials [8]. Water-soluble organic silica compounds, i.e. siloxanes, can be used as hydrophobizing agents in the amount of $1 \%-2 \%$ in relation to cement mass [9]. Silane and Siloxane impregnants were one of the first effective hydrophobic treatments to be used for enhancing concrete's impermeability of water and resistance to chemical attacks. Silicate resins is a hydrophobic material that forms a coating in the pores of the concrete and works on repelling water [10]. In addition, more popular are materials extracted from natural resources like natural oils, fatty acids and animal bloods [8]. Sodium acetate, fluoropolymer and silicone resin were an environmentally friendly alternative materials, especially efficient when were applied to wet surfaces [11]. Al-Kheetan et al. suggest that the efficacy of all impregnants determined in relation to moisture content within the concrete is important, which directly ensure the optimal dosage of protective materials, and thus the expected level of protection they could provide [12].

In view of the requirements for the subsoil below the road pavement structure - protection against scaling - the author of the publication proposed the use of an additive to the hydraulic binder in the form of a surfactant - diamidoamine lactate, which was produced from natural raw materials [13]. The publications [14], [15] confirmed the improvement of compressive strength and frost resistance of cohesive soils stabilized with cement with the addition of the above-mentioned hydrophobizing agent. This publication deals with the subject of the susceptibility of cohesive soils stabilized with cement and a hydrophobizing agent to capillary absorption of water from the environment, which results in the formation of heaps destroying surfaces.

\section{Materials}

The stabilization was carried out on two cohesive soils: loamy sand (Pg) and sandy loam (Gp), which results in the formation of layers that destroy the surface. Both examined cohesive 
soils have the same origin, they are the result of the erosion and accumulation of the North Polish continental glacier, the Leszno phase. The main difference is the clay content which determines the soil type - less than $2 \%$ for loamy sand and more than $2 \%$ for sandy loam. The grain size distribution is shown in Fig 1, and the basic properties are shown in Table 1. The obtained sand indexes confirm their heaping character (according to [16], [17]).

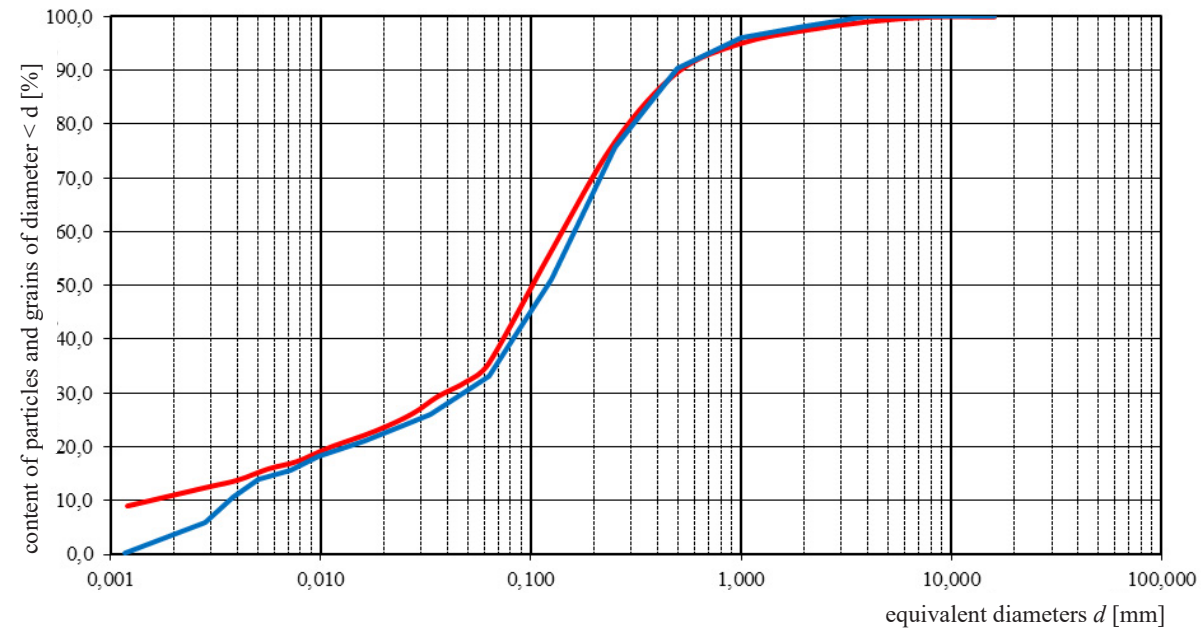

Fig. 1. The particle size distribution curves of the tested soils - red Gp, blue Pg

Table 1. Properties of the investigated soils

\begin{tabular}{llll}
\hline & Values & Values \\
\hline Loamy sand: & & Sandy loam: & \\
\hline clay fraction content [\%] & 3.4 & clay fraction content [\%] & 11.0 \\
\hline yield point [\%] & 14.6 & yield point [\%] & 12.0 \\
\hline liquidity limit [\%] & 21.5 & liquidity limit [\%] & 25.7 \\
\hline plasticity index [\%] & 6.9 & plasticity index [\%] & 13.7 \\
\hline sand indicator [-] & 17 & sand indicator [-] & 8 \\
\hline optimal humidity [\%] & 10.0 & optimal humidity [\%] & 10.7 \\
\hline $\begin{array}{l}\text { maximum bulk density } \\
\left.\text { [g/cm }{ }^{3}\right]\end{array}$ & 2.00 & $\begin{array}{l}\text { maximum bulk density } \\
{\left[\mathrm{g} / \mathrm{cm}^{3}\right]}\end{array}$ & 2.01 \\
\hline soil pH & 7.13 & soil pH & 7.95 \\
\hline
\end{tabular}

Common cement CEM II B-S 32.5 R, meeting the requirements of the standard [18], was used as a hydraulic binder for the tests. Cement was chosen because of the popularity of its practical application on construction sites, as it is often used in road construction as a stabilizing binder. The setting time of the cement was 121 minutes, and its average compressive strength, determined after 28 days of hardening, was $47.5 \pm 0.6 \mathrm{MPa}$. The hydrophobizing additive was made with the use of waste fats - used vegetable and animal oils. The process of obtaining diamidoamine lactate is shown in Fig 2. 


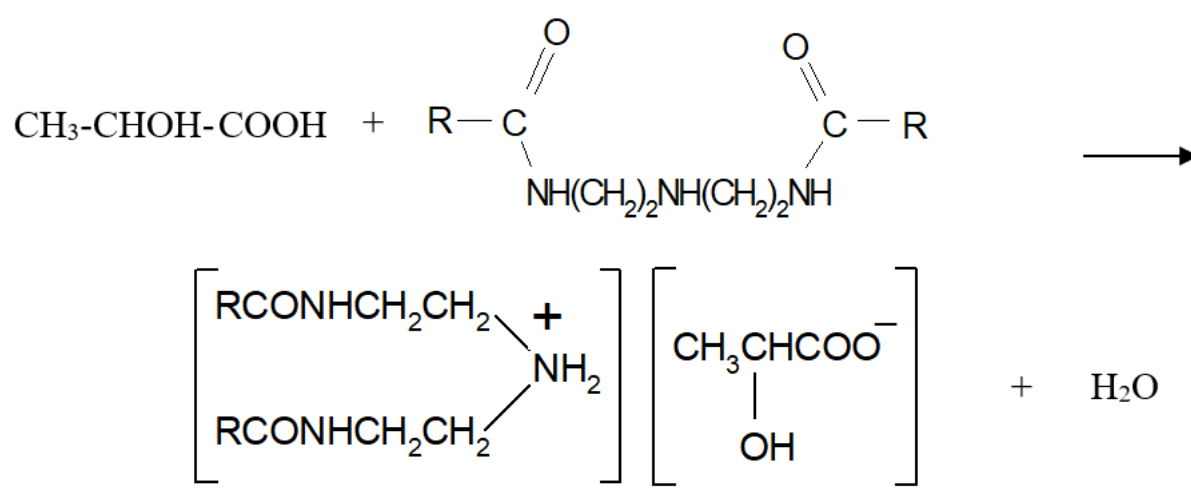

Fig. 2. Scheme of the reaction for the preparation of diamidoamine lactate. Source: [13]

The cement addition ranged from 5\% to $9 \%$ with respect to the dry mass of the soil. Due to the exploratory - pilot nature of the research (diamidoamine lactate was used for the first time as an additive for soil hydrophobization), the amount of lactate was added alternatively, ranging from $3 \%$ to $9 \%$ in relation to dry weight. From among the prepared mixtures for capillary water absorption tests, the ones that achieved the highest frost resistance indexes in individual groups were selected (see Table 2 [19]).

Table 2. The values of compressive strength and frost resistance indexes of the tested mixtures. Source: [19]

\begin{tabular}{|c|c|c|c|c|c|}
\hline & \multirow{2}{*}{$\begin{array}{l}\text { Mark } \\
\text { mixtures }\end{array}$} & \multicolumn{3}{|c|}{ Compressive strength $[\mathrm{MPa}]$ after the period } & \multirow{2}{*}{$\begin{array}{l}\text { frost resistance [-] } \\
\text { Indicator }\end{array}$} \\
\hline & & 7 days & 28 days & $\begin{array}{l}28 \text { days } \\
\text { (after } 14 \text { frozen cycles) }\end{array}$ & \\
\hline \multirow{6}{*}{$\begin{array}{l}\text { loamy sand } \\
\text { mixtures }\end{array}$} & $7 \% \mathrm{C}$ & 2.14 & 2.79 & 1.45 & 0.52 \\
\hline & $7 \% \mathrm{M}-7 \% \mathrm{C}$ & 2.24 & 3.62 & 1.27 & 0.35 \\
\hline & $9 \% \mathrm{M}-7 \% \mathrm{C}$ & 2.23 & 3.69 & 1.03 & 0.28 \\
\hline & $9 \% \mathrm{C}$ & 3.15 & 4.06 & 2.21 & 0.54 \\
\hline & $3 \% \mathrm{M}-9 \% \mathrm{C}$ & 2.56 & 4.65 & 3.52 & 0.76 \\
\hline & $5 \% \mathrm{M}-9 \% \mathrm{C}$ & 2.07 & 3.25 & 2.45 & 0.75 \\
\hline \multirow{8}{*}{$\begin{array}{l}\text { sandy loam } \\
\text { mixtures }\end{array}$} & $7 \% \mathrm{C}$ & 2.01 & 2.37 & 0.15 & 0.06 \\
\hline & $3 \% \mathrm{M}-7 \% \mathrm{C}$ & 1.72 & 2.95 & 1.60 & 0.54 \\
\hline & $5 \% \mathrm{M}-7 \% \mathrm{C}$ & 1.16 & 1.94 & 0.66 & 0.34 \\
\hline & $7 \% \mathrm{M}-7 \% \mathrm{C}$ & 1.42 & 2.75 & 0.55 & 0.20 \\
\hline & $9 \% \mathrm{C}$ & 2.37 & 4.59 & 0.46 & 0.10 \\
\hline & $3 \% \mathrm{M}-9 \% \mathrm{C}$ & 1.87 & 3.15 & 1.91 & 0.61 \\
\hline & $5 \% \mathrm{M}-9 \% \mathrm{C}$ & 2.23 & 3.15 & 1.00 & 0.32 \\
\hline & $7 \% \mathrm{M}-9 \% \mathrm{C}$ & 2.31 & 3.62 & 1.55 & 0.43 \\
\hline
\end{tabular}




\section{Capillary water absorption studies}

Polish standards for soil stabilized with cement [7], [20], [21] do not require or define capillary water absorption studies. The methodology of determining capillarity is commonly used in the case of testing masonry elements [22], [23]. The test algorithm was taken from the PN-EN 772-11:2011 standard [24]. The following materials and research devices were used for the measurements:

- ventilated dryer with the possibility of maintaining the temperature in the range of $105 \pm 5^{\circ} \mathrm{C}$

- vessels (steel sheets) with a depth greater than $20 \mathrm{~mm}$,

- stopwatch,

- potable water,

- laboratory balance with an accuracy of $0.1 \mathrm{~g}$.

After drying to constant weight and cooling to room temperature, the samples were immersed in the vessels to a depth of $5 \pm 1 \mathrm{~mm}$. The immersion depth was kept constant during the tests.

Water absorption measurement periods were assumed, counted from the moment of immersion of the samples in water: $10 \mathrm{~min}(600 \mathrm{~s}), 30 \mathrm{~min}(1800 \mathrm{~s}), 60 \mathrm{~min}(3600 \mathrm{~s}), 3 \mathrm{~h}$ (10 $800 \mathrm{~s}), 8 \mathrm{~h}(28800 \mathrm{~s}), 24 \mathrm{~h}(86400 \mathrm{~s}), 48 \mathrm{~h}$ (172 $800 \mathrm{~s}), 72 \mathrm{~h}$ (259 $200 \mathrm{~s}), 96 \mathrm{~h}$ (345 $600 \mathrm{~s})$,

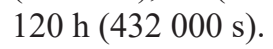

Before each mass measurement (after the specified saturation time), the sample was dried with a chamois leather.

The coefficient of water absorption due to the rising capillary was calculated in accordance with the standard [24], according to the Eq. 1:

$$
C_{w s}=\frac{m_{s o, s}-m_{d r y, s}}{A_{s} \sqrt{t_{s}}}
$$

where: $m_{\mathrm{dry}, \mathrm{s}}$ is a sample weight after drying [g], $m_{\mathrm{so}, \mathrm{s}}$ is a mass of the soaked sample at time $t$ [g], $A_{\mathrm{s}}$ is sample surface immersed in water $\left[\mathrm{m}^{2}\right], t_{\mathrm{s}}$ is saturation time $[\mathrm{s}], C_{\mathrm{ws}}$ is water absorption coefficient $\left[\mathrm{g} /\left(\mathrm{m}^{2} \mathrm{~s}^{0.5}\right)\right]$.

14 soil mixtures stabilized with cement, 6 mixtures made of clay sand and 8 mixtures of sandy loam were tested. Each test series consisted of 3 samples for which the mean capillary absorption as a function of the element of the immersion time was calculated and the mean water absorption after selected measurement periods was determined.

\section{Research results and their analysis}

\subsection{Macroscopic evaluation during research}

The samples, dried at the temperature of $105-110{ }^{\circ} \mathrm{C}$, were immersed at $5 \pm 1 \mathrm{~mm}$ in water and subjected to water capillary rising tests. Along with the increasing time of soaking in water, changes in the saturation level of the samples were visible (see Figs 3-6). 


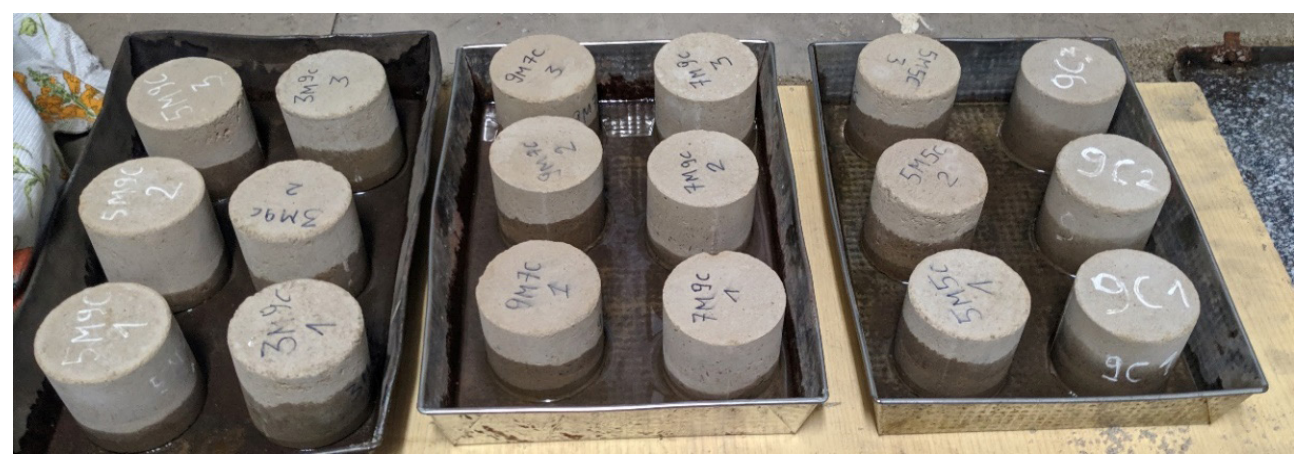

Fig. 3. Capillarity test - view 3 hours after immersion - Pg mixtures

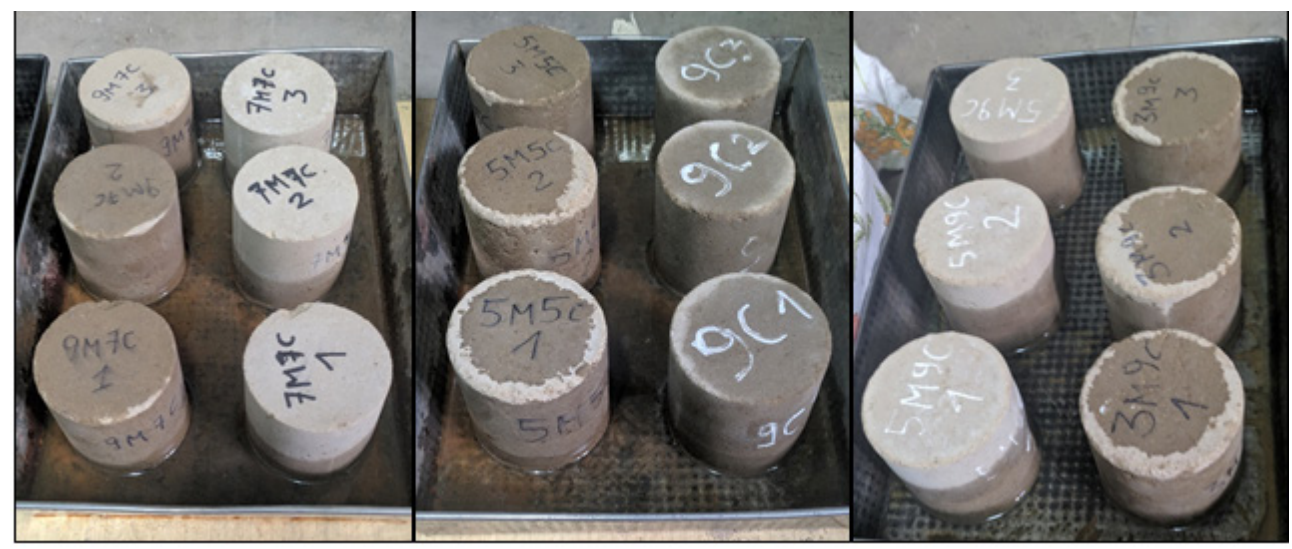

Fig. 4. Capillarity test - view 24 hours after immersion - Pg mixtures

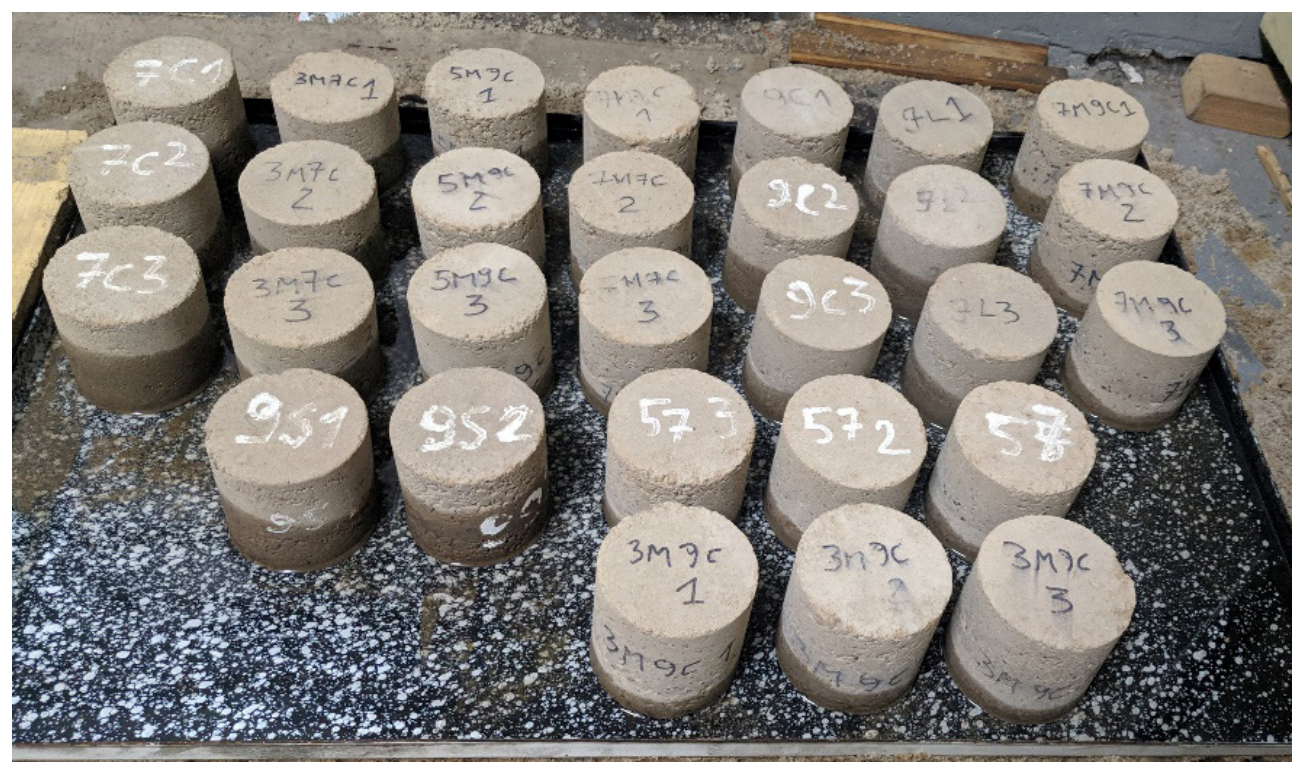

Fig. 5. Capillarity test - view after 3 hours from immersion - Gp mixtures 


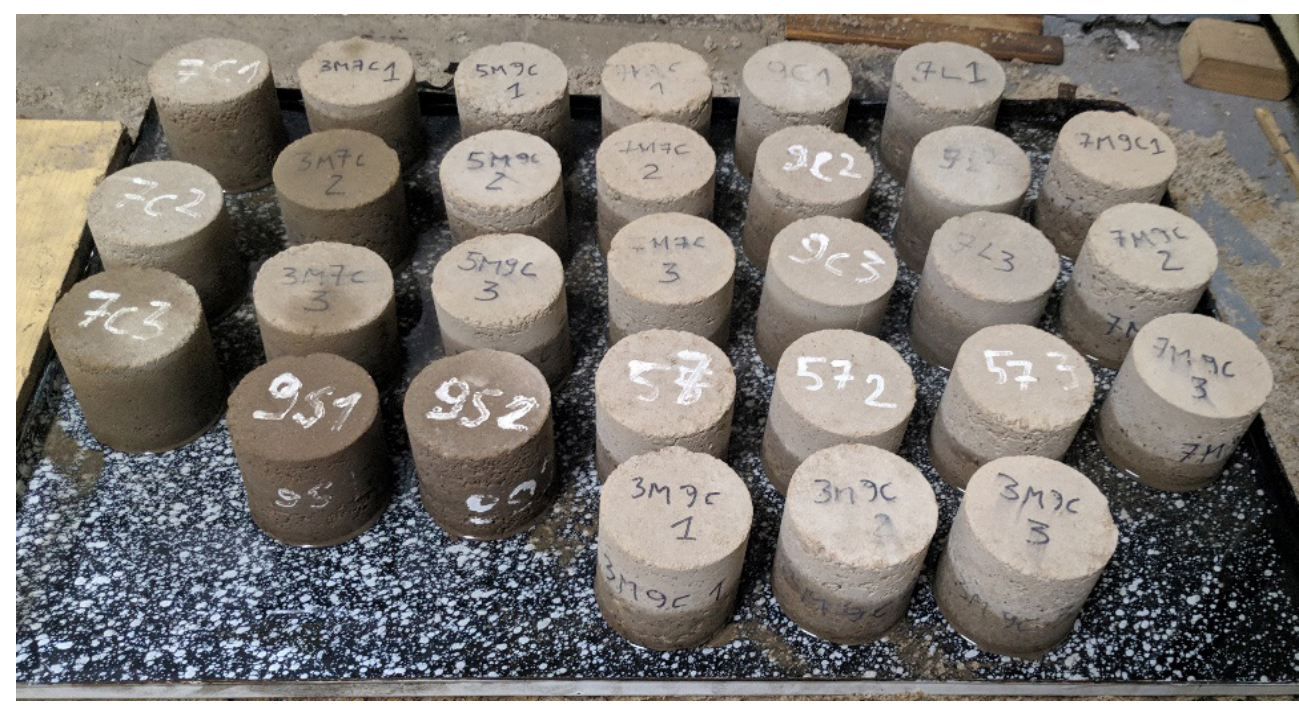

Fig. 6. Capillarity test - view 24 hours after immersion - Gp mixtures

Mixtures in which, in addition to cement, diamidoamine lactate was added, compared to the reference (cement) mixes absorbed water much slower. In the case of mixtures made of loamy sand, water penetrated much faster along the entire height of the sample. Sandy loam mixtures - due to their higher cohesiveness than loamy sand - which are also characterized by lower water permeability, absorbed water much slower. Moreover, samples into which water had penetrated to its full height showed drying and peeling of the edge of the upper surface

\subsection{Loamy sand mixtures}

The course of changes in the mass of the samples related to their surface area in contact with water as a function of the square root of time is illustrated in Figs 7 and 8.

Water absorption caused by capillary rise depending on the amount of binder used after selected measurement periods is shown in Figs 9 and 10.

The capillary rise of water increases, as well as the values of the amount of water absorbed (see Figs 9 and 10) presented in Figs 7 and 8, allow to conclude that the addition of diamidoamine lactate limits the possibility of capillary rising of water in soils stabilized with cement, especially in the initial absorption period (up to 8 hours). Later in the test, when the sample is saturated with water, the amount of water pulled up is comparable for all mixtures. The addition of lactate in an amount of less than $60 \%$ of the binder quantity reduces the amount of water absorbed in the initial period by almost three times. In the case of significant addition of a hydrophobizing agent (more than the hydraulic binder), lactate increased the absorption. The above may be caused by too high affinity for water (lactate is a $10 \%$ solution of the active substance in water). Referring to the frost resistance results, it should be noted that the mixtures characterized by lower capillarity obtained higher frost resistance.

\subsection{Sandy loam mixtures}

The course of the sample mass change in relation to their surface area in contact with water as a function of the square root of time is illustrated in Figs 11 and 12. 


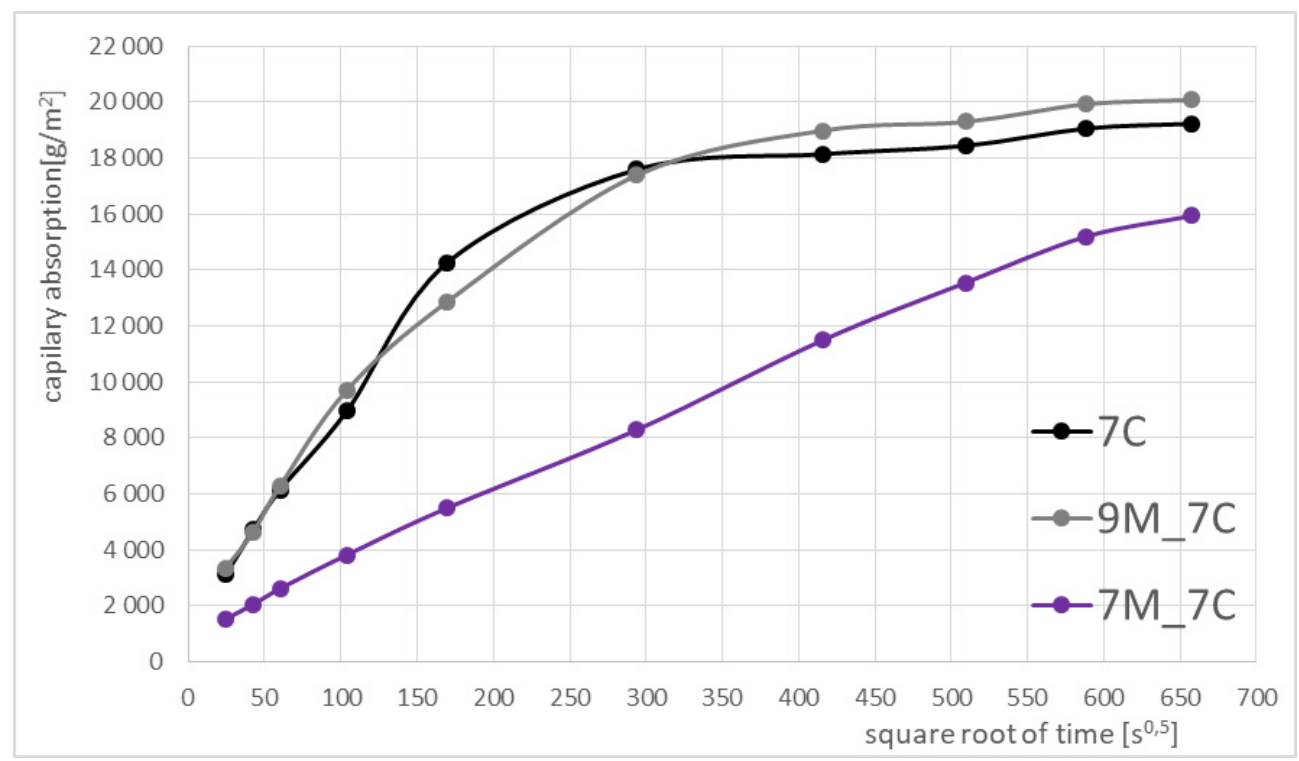

Fig. 7. Graph of capillary absorption of Pg mixtures with 7\% binder content and optional addition of diamidoamine lactate

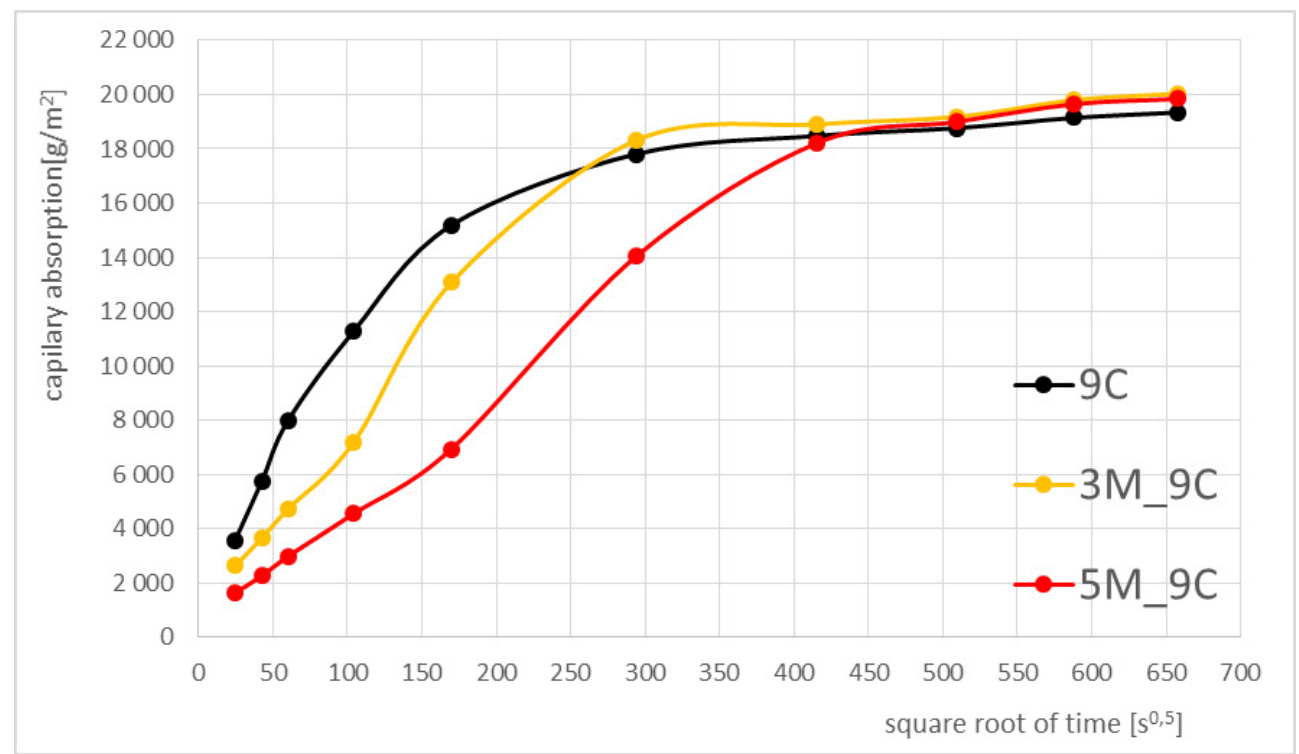

Fig. 8. Graph of capillary absorption of Pg mixtures with $9 \%$ binder content and optional addition of diamidoamine lactate 


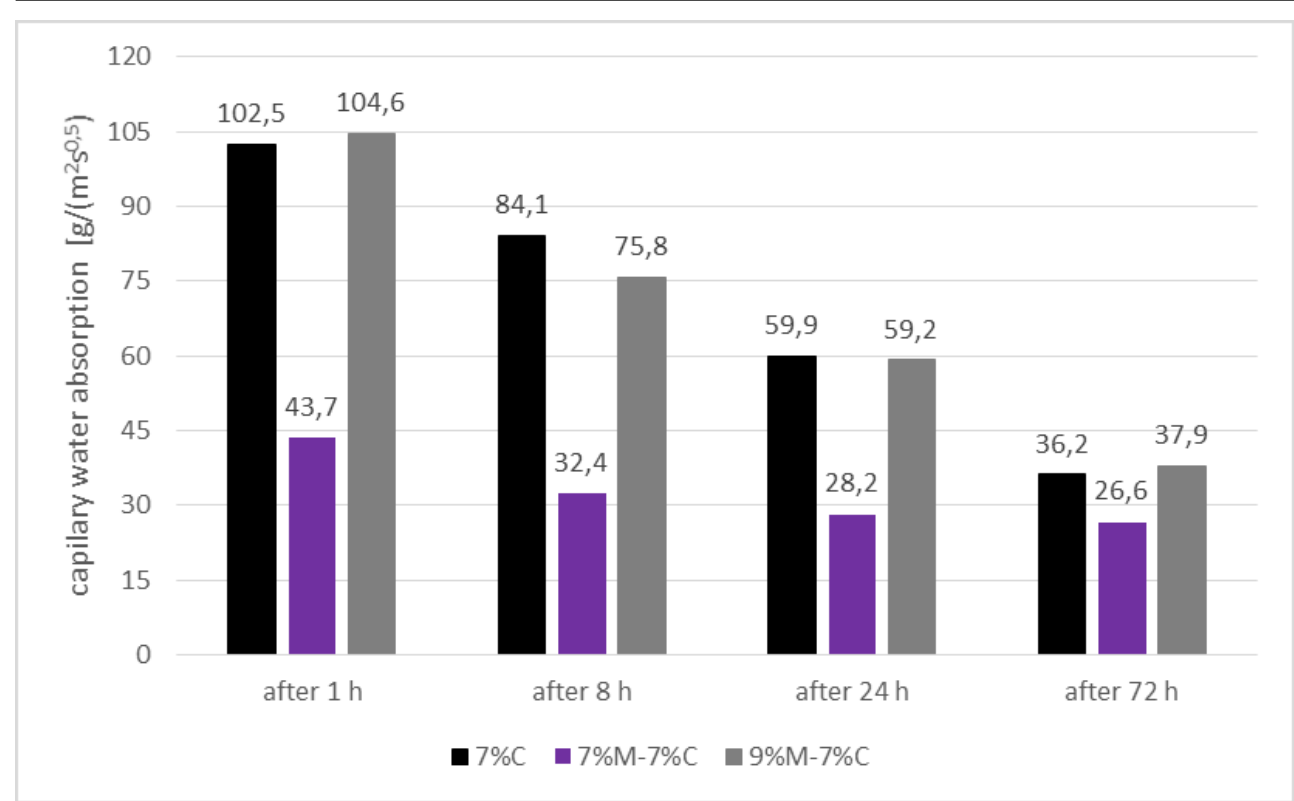

Fig. 9. Capillary water absorption values of Pg mixtures with $7 \%$ binder addition for selected measurement periods

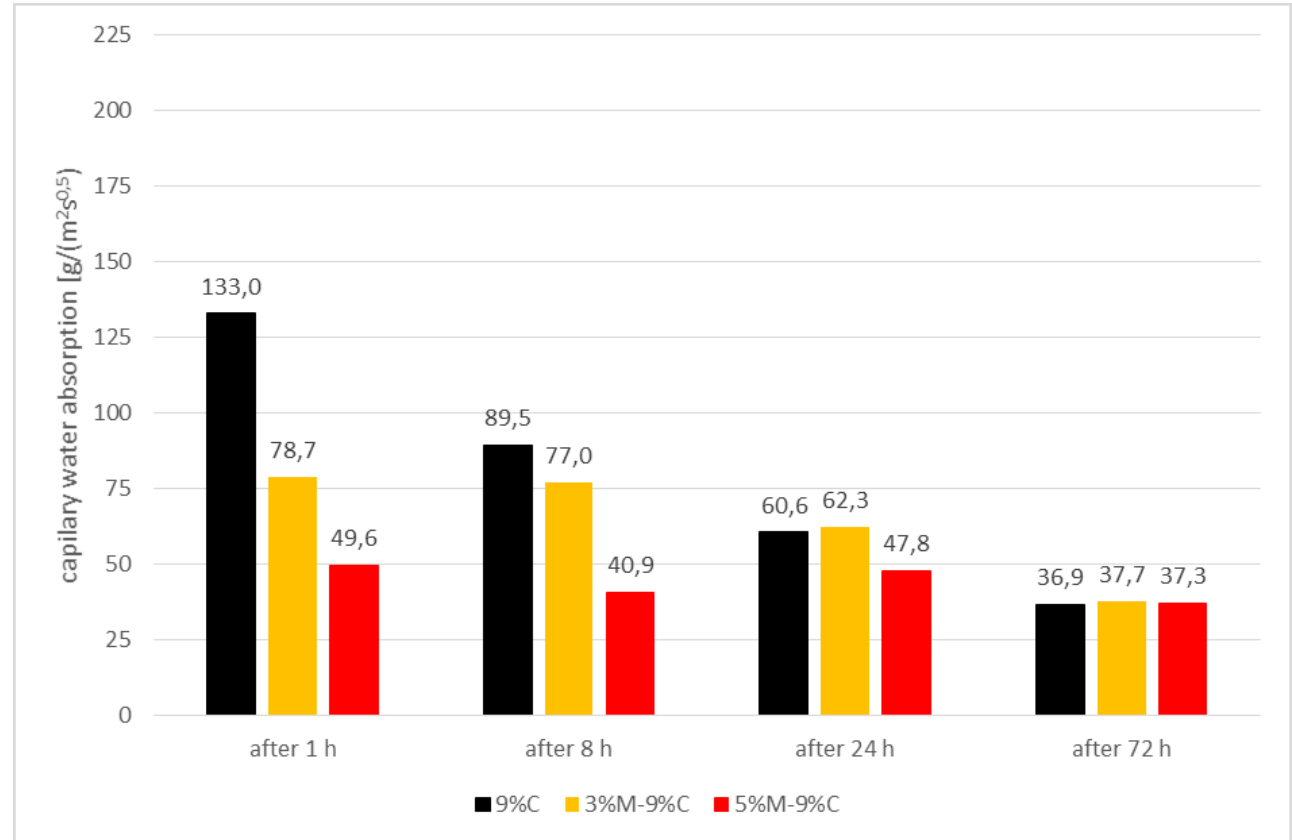

Fig. 10. Capillary water absorption values of Pg mixtures with $9 \%$ binder addition for selected measurement periods

Water absorption of sandy loam mixtures caused by capillary rise depending on the amount of binder used after selected measurement periods is shown in Figs 13 and 14 


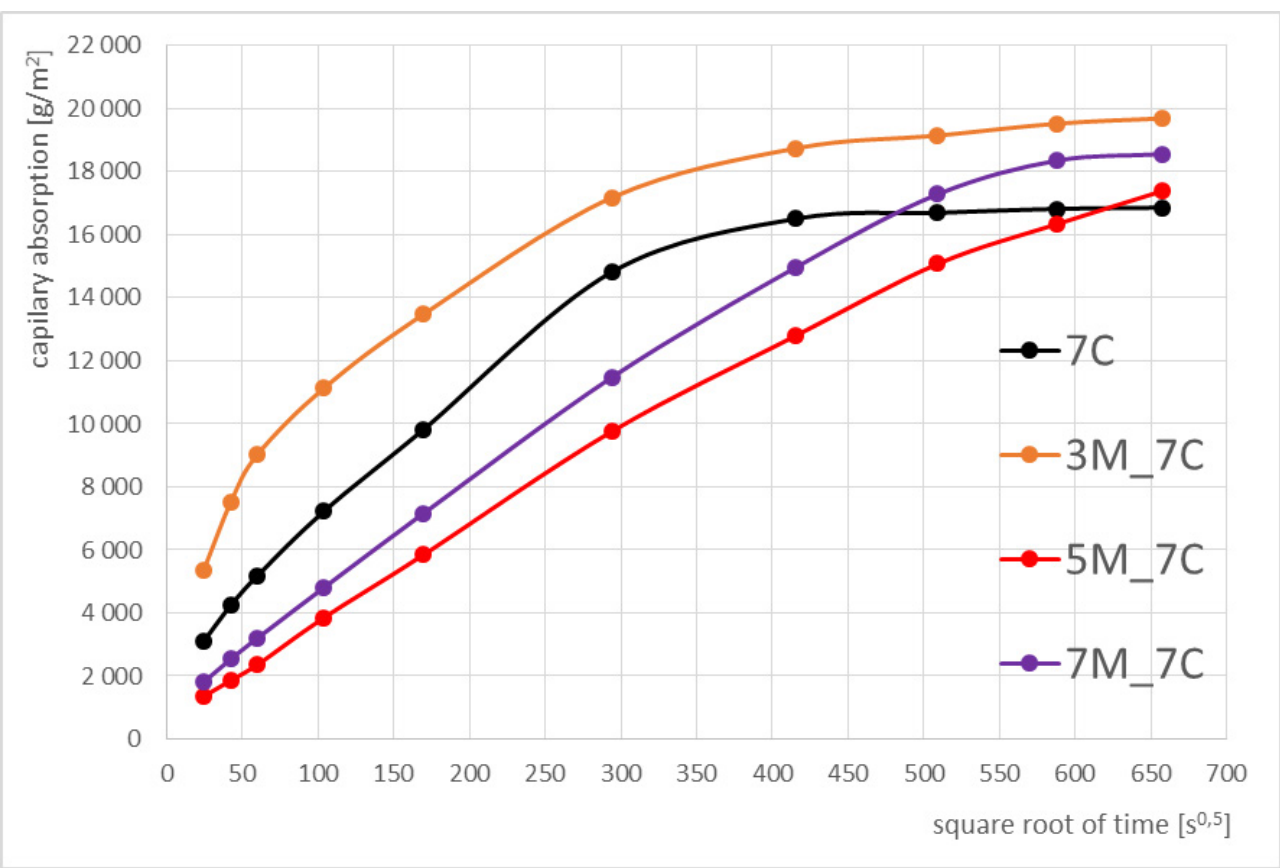

Fig. 11. Graph of capillary absorption of Gp mixtures with $7 \%$ binder content and optional addition of diamidoamine lactate

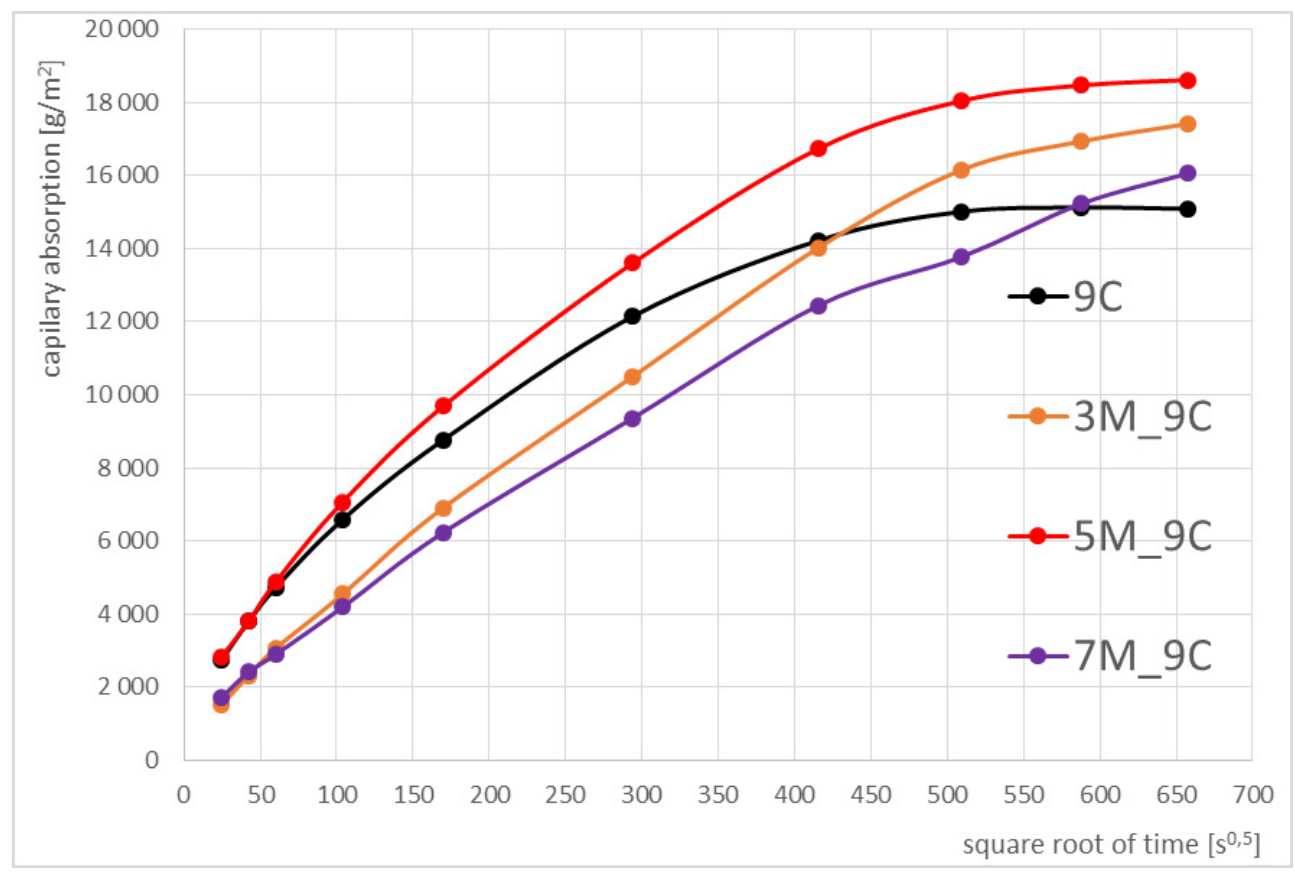

Fig. 12. Graph of capillary absorption of Gp mixtures with $9 \%$ binder content and optional addition of diamidoamine lactate 


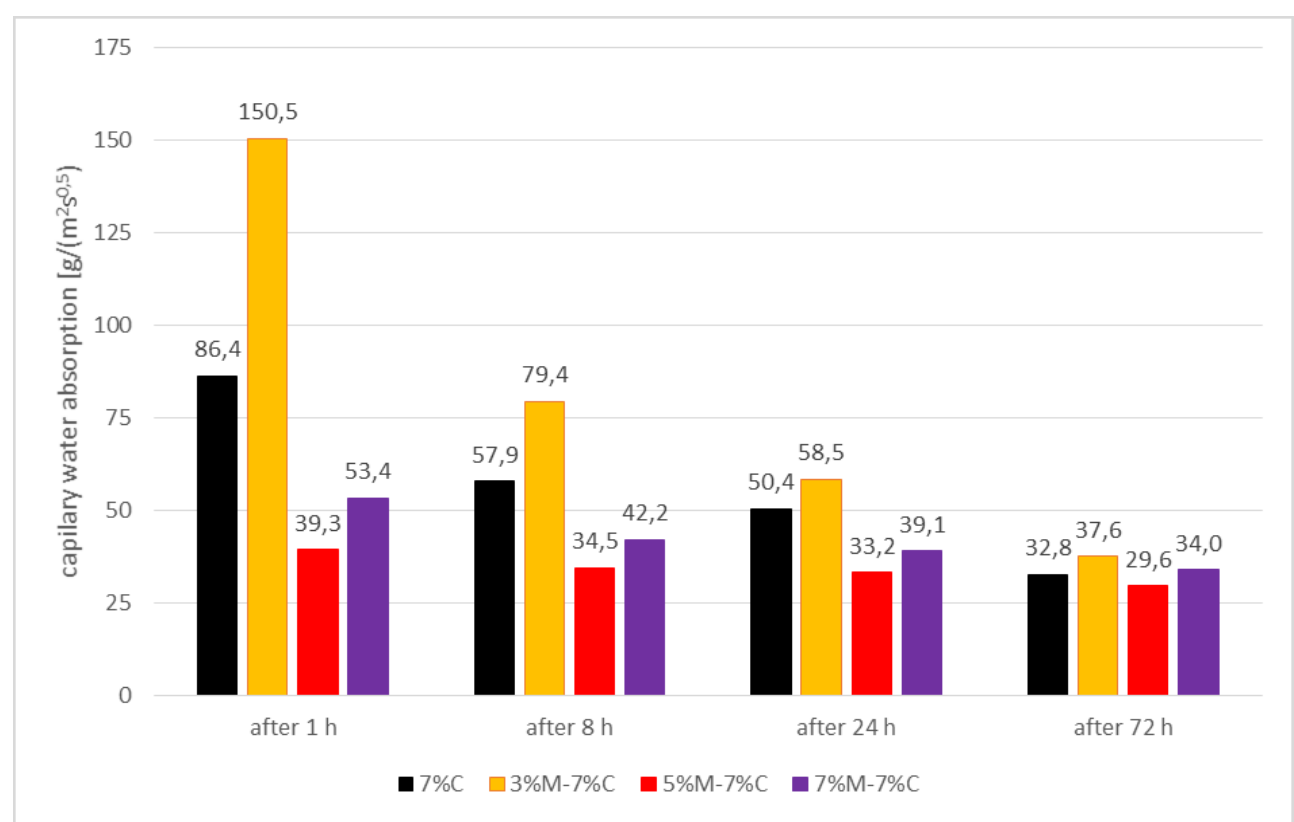

Fig. 13. Capillary water absorption values of $\mathrm{Gp}$ mixtures with $7 \%$ binder addition for selected measurement periods

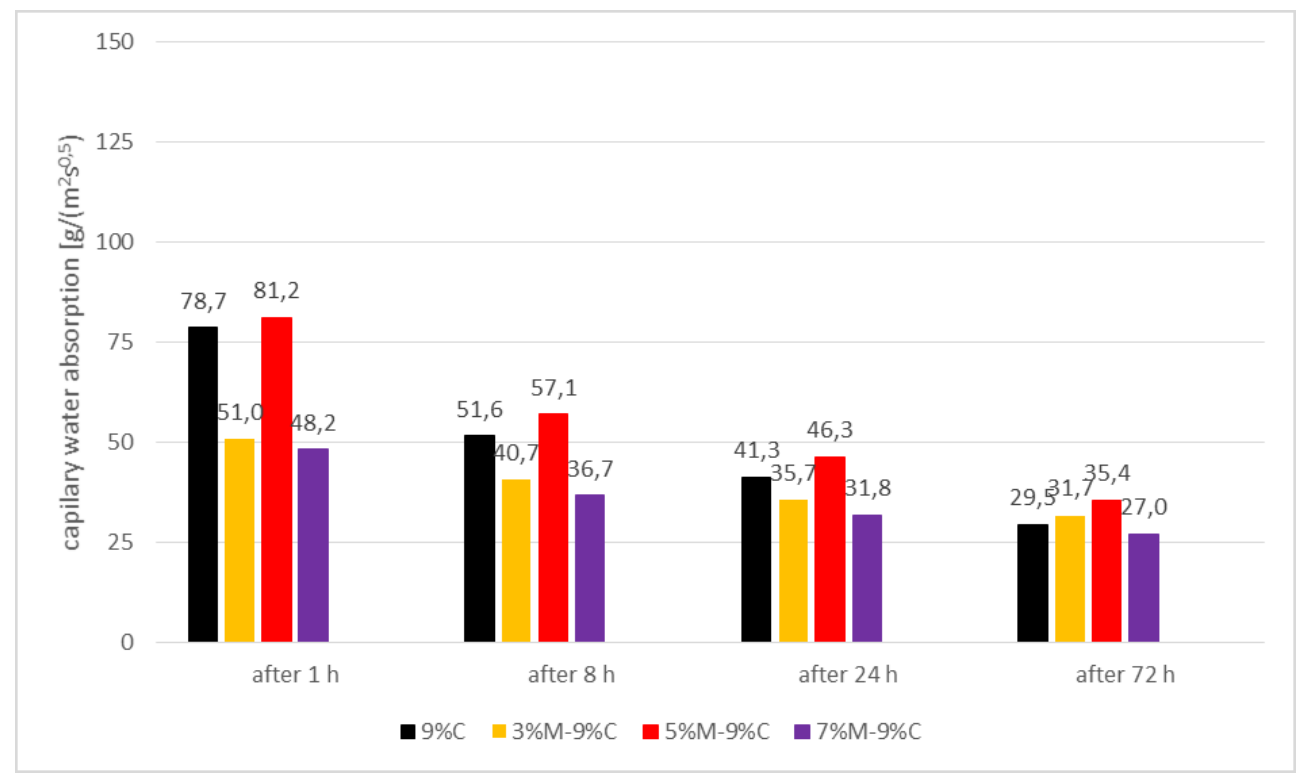

Fig. 14. Capillary water absorption values of $\mathrm{Gp}$ mixtures with $9 \%$ binder addition for selected measurement periods

When analyzing the illustrated increases in capillary rise of water and the amount of water absorbed, it should be noted that in the case of mixtures with $7 \%$ cement addition only $5 \%$ and $7 \%$ addition of diamidoamine lactate allowed to obtain a lower capillarity of the tested 
samples. In the case of mixtures with $9 \%$ cement content, the addition of a hydrophobizing agent in the amount of $3 \%$ and $7 \%$ allowed to reduce capillary absorption. Compared to loamy sand mixtures, it cannot be clearly determined what amount of additive is optimal to limit capillary water absorption of loam clay mixtures.

\section{Conclusions}

In road construction, an important aspect of proper substrate preparation is ensuring its frost resistance. Due to the molecular structure and low water permeability, cohesive soils should not be present in the frost zone. By using soil stabilization with hydraulic binders, we can increase their bearing capacity and improve frost resistance. The recommended, standard amounts of hydraulic binder do not allow for high frost resistance parameters for cohesive soils. Improvement in the frost resistance indices was found in the case of the addition of diamidoamine lactate as a hydrophobizing agent. In order to evaluate the effect of the hydrophobizing additive, studies of capillary water absorption of the mixtures stabilized in this way were undertaken. Due to the lack of typical methods of assessing capillary water absorption by soil mixtures stabilized with a binder, the author of the publication proposed a methodology taken from the study of masonry elements.

For loamy sand, the reduction of water penetration was observed with the addition of a hydrophobizing agent in an amount not exceeding 5\% of the dry soil mass. The mixtures were characterized by lower water absorption, especially in the first hours after soaking with water, which means that the stabilized mixture will absorb water slower from the environment immediately after execution. For mixtures made of sandy loam, which is a more cohesive soil with a higher content of clay particles, which have an impact on low water permeability, it was observed that water penetrates slower inside the samples. The addition of a hydrophobizing agent reduces capillary water absorption, but the exact relationship between the amount of additive and the possibility of reducing water capillary rise cannot be determined. Unlike loamy sand mixes, higher amounts of hydrophobizing agent additive reduce water ingress inside the mix.

\section{References}

[1] Wiłun Z., Zarys geotechniki, Warszawa: WKiŁ, 2013

[2] Rafalski L., Wilczek J., Kraszewski C., „Ochrona przeciwmrozowa nawierzchni drogowych na przykładzie wybranych krajów”, Drogownictwo, no. 2, (2014), pp. 39-45.

[3] Cyske W. and Kluska I., „Porównanie właściwości wybranych środków do stabilizacji gruntów na budowie autostrady A1", Drogi i mosty, vol. 6, no. 1, (2007), pp. 5-17.

[4] Glinicka M., „Właściwości geotechniczne gruntów spoistych z terenu Białegostoku wzmacnianych cementem lub wapnem", Drogi i mosty, vol. 5, np. 4, (2006) pp. 23-39.

[5] Kamiński B., „Bezpieczna dla środowiska stabilizacja cementem portlandzkim leśnych gruntów drobnoziarnistych", Zarządzanie Ochroną Przyrody w Lasach, vol. 2, (2008), pp. 272-278.

[6] Porszke A., „Analiza właściwości gruntów stabilizowanych spoiwem Silment CQ-25 w różnych warunkach pielęgnacji próbek-artykuł dyskusyjny", Drogownictwo, no. 9-10, (2006), pp 318-320.

[7] PN-S-96012:1997 "Roads - Subbase and subgrade of cement stabilised soils"

[8] Al-Kheetan M.J., Rahman M.M., Chamberlain D.A., "Moisture evaluation of concrete pavement treated with hydrophobic surface impregnants", International Journal of Pavement Engineering, vol. 21, no. 14, (2020), pp. 1746-1754. https://doi.org/10.1080/ 10298436.2019.1567917 
[9] Suchorab Z., Barnat-Hunek D., Franus M., Lagod G.: "Mechanical and Physical Properties of Hydrophobized Lightweight Aggregate Concrete with Sewage Sludge", Materials, vol. 317, no. 9, (2016), pp 1-18. https://doi.org/10.3390/ma9050317

[10] Dai J.G., Akira Y., Wittmann F.H., Yokota H., Zhang P., "Water repellent surface impregnation for extension of service life of reinforced concrete structures in marine environments: the role of cracks", Cement and Concrete Composites, vol. 32, no. 2, (2010), pp. 101-109. https://doi. org/10.1016/j.cemconcomp.2009.11.001

[11] Al-Kheetan M.J., Al-Tarawneh M.A., Ghaffar S.H., Chougan M., Jweihan Y.S., Rahman M.M., "Resistance of hydrophobic concrete with different moisture contents to advanced freezethaw cycles", Structural Concrete, vol. 22, no. S1, (2021) pp. 1-12. https://doi.org/10.1002/ suco.202000214

[12] Al-Kheetan M.J., Rahman M.M., Balakrishna M.N., Chamberlain D.A., "Performance enhancement of self-compacting concrete in saline environment by hydrophobic surface protection", Canadian Journal of Civil Engineering, vol. 46, no. 8, (2019), pp. 677-686. https://doi.org/10.1139/ cjce-2018-0546

[13] Babiak M., Kosno J., Węgliński S., Jaszkiewicz, A., "Research on the influence of a hydrophobicizing agent based on amidoamines on frost resistance and durability of cohesive soils", Przemyst chemiczny, vol. 95, no. 11, (2016) pp. 2376-2379. https://doi.org/10.15199/62.2016.11.48

[14] Babiak M., Kosno J., Węgliński, S., „Ekologiczny środek do stabilizacji gruntów spoistych zwiększający ich wytrzymałość i mrozoodporność”, Materiały budowlane, no. 2, (2017), pp. 24-26. https://doi.org/10.15199/33.2017.02.06

[15] Błaszczyński T., Babiak M., Kosno J., Węgliński S., "Freeze-thaw Resistance and Increased Strength of Cohesive Soils Modified with a Cationic Surfactant", Procedia Engineering, vol. 172, (2017), pp. 111-118. https://doi.org/10.1016/j.proeng.2017.02.032

[16] Katalog typowych konstrukcji nawierzchni podatnych i pótsztywnych, Generalna Dyrekcja Dróg Krajowych i Autostrad, Warszawa: 2014

[17] PN-S-02205: 1998 "Roads - Earthwork - Specifications and testing"

[18] PN-EN 197-1: 2012 "Cement-Part 1: Composition, specifications and conformity criteria for common cements"

[19] Węgliński S., "The effect of hydraulic road binders and cement with diamidoamine lactate additive on the compressive strength and freeze-thaw resistance of cohesive soils", Cement, Lime, Concrete, vol. 25, no. 6, (2020), pp. 432-443. https://doi.org/10.32047/cwb.2020.25.6.1

[20] PN-EN 14227-10:2006 "Hydraulically bound mixtures - Specifications - Part 10: Soil treated by cement"

[21] PN-EN 14227-15: 2015-12 "Hydraulically bound mixtures - Specifications - Part 15: Hydraulically stabilized soils"

[22] Garbalińska H., Głowacka A., „Symulacyjne badania dotyczące rozprzestrzeniania się zawilgocenia kapilarnego w ścianach z bloczków silikatowych”, Polska Energetyka Słoneczna, vol. 43, no. 1-4, (2015), pp. 55-58.

[23] Garbalińska H., Cederholm A., „Współczynnik sorpcji betonu komórkowego badany na próbkach suszonych i niesuszonych”, Czasopismo Inżynierii Lądowej, Środowiska i Architektury, vol. 61, no. 3/II, (2014), pp. 163-172.

[24] PN-EN 772-11:2011 "Methods of test for masonry units - Part 11: Determination of water absorption of aggregate concrete, autoclaved aerated concrete, manufactured stone and natural stone masonry units due to capillary action and the initial rate of water absorption of clay masonry units" 
